\title{
Examining the Relationship Between Supply Chain Management Practices and Production Performance in Indian Handloom Industry
}

\author{
Kalyani Anumala, Siva Sivani Institute of Management, Hyderabad, India
}

(iD) https://orcid.org/0000-0002-8515-4329

\begin{abstract}
Clothing is one of the basic needs of human beings and first produced by using handlooms. Cloth can be produced by three ways: using handloom, power loom, and mills. Mill sector falls under organized sector, where as the handloom and power looms fall under unorganized sector. The supply chain in this unorganized sector is different and not given any importance. The main aim of the study is to examine the relationship between supply chain management practices and production performance in Indian handloom industry. Data is collected from the master weavers of Undivided State of Andhra Pradesh and analysed using structural equation modeling. The study found that there is a relationship between the supply chain management practices and production performance.
\end{abstract}

\section{KEYWORDS}

Handloom Industry, Master Weaver, Production Performance (PPERF), Supply Chain Management, Supply Chain Management Practices (SCMP)

\section{INTRODUCTION}

Clothing is one of the primary needs of mankind. This need led to the invention of handloom, which ultimately developed into industry in the course of time (Narsaiah, 2004).

As per the annual report of Ministry of Textiles (2019), "traditional sectors like handloom, handicrafts and small scale power-loom units are the biggest source of employment for millions of people in rural and semi urban area and also contribute to more than $75 \%$ of total textiles production in the country. Handloom weaving provides employment to more than 43 lakh weavers and allied workers. This is the one of the largest employment providers after agriculture. This sector contributes to $15 \%$ of the cloth production in the country and also contributes to the export earnings." The export fabrics are of high value and also caters to the fashion market. According to Haddad \& Otayek (2019), the worldwide fashion industry is one of the most competitive sectors of the global economy where a vast number of manufacturers compete without geographic boundaries, producing countless product varieties at an extremely fast pace, and for smaller and smaller profit margins.

According to Lee (2000), the role of manufacturers in the supply chain is critical for the efficiency of the whole supply chain because they have to build a direct relationship with suppliers as well as with customers and handle both interfaces efficiently. Keeping this in view the study is carried out to 
examine the Relationship between Supply Chain Management Practices and Production Performance in Indian Handloom Industry.

"Supply chains have become more complex in today's global environment primarily due to the shorter product life cycles, increasing demand, and complicated business strategies" (Iqbal\& Shalij 2019).

Due to weak supply chain linkages like information flow, transportation problems there exists a production problem which leads to the non-satisfaction of customers. The supply chain integrates all the elements like information flow, transportation which leads to production performance which in turn leads to product quality. Hence the study aims to find out the supply chain management practices followed in handloom sector with special reference to master weavers and to examine the relationship between supply chain management practices and production performance, as he is the one who takes care of all the linkages of supply chain.

La Londe's study (as cited in Chen \& Paulraj, 2004), "The term supply chain management (SCM) was originally introduced by consultants Oliver and Webber in the early 1980s and has subsequently gained tremendous attention".

\section{LITERATURE REVIEW}

As cited by Anilkumar \& Sridharan, 2019 (Christopher, 1992) defines supply chain management as "a network of organizations that are involved, through upstream and downstream linkages, in the different processes and activities that produce value in the form of products and services in the hands of the ultimate customer".

As cited by Kumar \& Anbanandam, 2019 (Baker, 2000) the main objective of doing any literature review is to identify the central theme of a topic or subject, with the aim of identifying the previous research and progress of research, as well as the related gaps that remain less discussed in the literature.

\section{Supply Chain in Textiles}

Table 1 shows the Literature on Supply Chain in Textiles.

\section{Handloom Supply Chain (HSC)}

The handloom supply chain involves the most important stages of fibre production, yarn production, and fabrication (see Figure 1).

\section{Stage I: Fibre Production}

The first stage in the handloom supply chain is production of fibre. Fibre is the primary material that is essential to produce any type of fabric. Fibres can be classified in to two types: (i) natural \& (ii) manmade or synthetic fibres. Fibre is obtained after undergoing a process called ginning.

\section{Stage II: Yarning/Spinning}

Second stage in handloom supply chain consists of transforming the natural fibres into yarns. Here fibre is spun in the spinning mills where in the mechanical process they are kept in the lengthwise direction and twisted in order to convert into the yarns either single or folded. Yarns are produced in regular and fancy varieties.

\section{Stage III: Fabric Production}

It is the most important stage. Fabric can be produced by weaving or knitting. Weaving is interlacing the length wise and width wise yarns. This can be done in three production structures in handloom sector namely, Cooperative structure, Master weaver structure and Individual weaver structure. 
Table 1. Literature on Supply Chain in Textiles

\begin{tabular}{|c|c|}
\hline Author and Year & Details \\
\hline Kaya \& Öztürk, 2014 & $\begin{array}{l}\text { Supply chain in textile is described as the chain of the firms being suppliers } \\
\text { to each other which is formed in the process from the production of textile } \\
\text { production material from cotton to deliver the end product to customers. } \\
\text { Supply chain in textile industry consists of a lot of procedures, suppliers, } \\
\text { middleman and customers. Knowledge and physical product flow are } \\
\text { important in this chain. }\end{array}$ \\
\hline Giri \& Rai, 2013 & $\begin{array}{l}\text { In their study on dynamics of garment supply chain found that the Indian } \\
\text { garment industry is facing many supply chain issues like, visibility, lead } \\
\text { time, inventory management, collaboration, technology and logistics. }\end{array}$ \\
\hline Nema et al., 2013 & $\begin{array}{l}\text { Conducted a literature review on the green supply chain management } \\
\text { practices in textile \& apparel industry. }\end{array}$ \\
\hline Berdine, et al., 2008 & $\begin{array}{l}\text { Textiles provide major input to the clothing industry, creating vertical } \\
\text { linkages between these two industries, forming a supply chain. A supply } \\
\text { chain is defined as the network of storage facilities, suppliers, distributors, } \\
\text { transporters, retailers, and that participate in the sale, delivery \& production } \\
\text { of a particular product. }\end{array}$ \\
\hline Lam \& Postle, 2006 & $\begin{array}{l}\text { Have reviewed the concept of supply chain management in textile \& apparel } \\
\text { supply chain management in Hong Kong. They discussed the strengths } \\
\text { \&problems faced by the Hong Kong textile \&apparel supply chains. They } \\
\text { argued that Hong Kong apparel industry is generally not aware of the } \\
\text { concept of supply chain management \& industrial benchmark for both } \\
\text { manufacturing \& retailing industries in Hong Kong \& the supply chain } \\
\text { performance is below the world average. }\end{array}$ \\
\hline Lee \& Kincade, 2003 & $\begin{array}{l}\text { Have studied the level of SCM activities \& examined the relationship of } \\
\text { selected company characteristics for a set of US apparel manufacturer } \\
\text { companies \& identified six dimensions of SCM namely partnership, } \\
\text { operational flexibility, performance measurement, management } \\
\text { commitment, information technology, and demand characterization. They } \\
\text { advocate that apparel manufacturers have more partnership type relationship } \\
\text { with their supply chain members. }\end{array}$ \\
\hline Chandra \& Kumar, 2000 & $\begin{array}{l}\text { Described the application of a supply chain analysis methodology for } \\
\text { managing waste due to the inventory-related logistics in a garment supply } \\
\text { chain of the US textile industry. }\end{array}$ \\
\hline
\end{tabular}

\section{Supply Chain Management Practices (SCMP)}

Table 2 shows the Literature on Supply Chain Management Practices.

After reviewing and consolidating the literature, four distinctive sub-constructs were selected for measuring SCM Practices (see Table 3). These cover upstream (strategic supplier partnership) and downstream (customer relationship) sides of a supply chain, information flow across a supply chain. Supply chain management practices in the study is operationalized by the four distinct practices are:

1. Strategic Supplier Partnership (SSP);

2. Customer Relationship (CR);

3. Information Sharing (IS); and

4. Information Quality (IQ).

\section{Production Performance (PPERF)}

Table 4 shows the Literature on Production Performance. 
Figure 1. The supply chain of handloom products

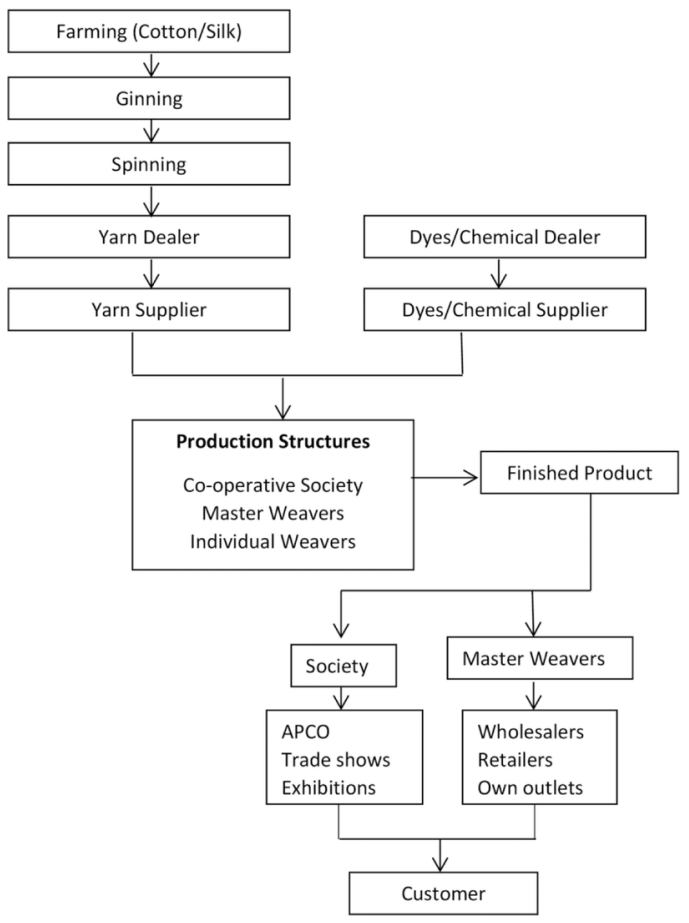

Durability depends on the type of dyes used and the method of processing followed. Usage of poor dyes and chemicals leads to poor fastness to colour, wash, rubbing, and perspiration. Poor colour fastness products on the dye molecules and heavy metal ions may be absorbed into the body through the skin against skin and even damage to health.

Lack of finance is the severest problem followed by the excessiveness of yarn price is perceived to be the second most pressing difficulty.

Production performance in this study is operationalized by Quality, Cost, Flexibility and Delivery. The sub-constructs considered to measure production performance (see Table 5).

\section{METHODOLOGY}

\section{Research Objective}

To examine the relationship between supply chain management practices and production performance in Indian Handloom Industry.

\section{Research Hypothesis}

$\mathbf{H}_{\mathbf{1}}$ : There is a significant relation between supply chain management practices and production performance.

\section{Research Design}

The present study employs the explorative and descriptive research designs and follows qualitative and quantitative research approach (see Figure 2). 
Table 2. Supply Chain Management Practices (SCMP)

\begin{tabular}{|c|c|}
\hline Author and Year & Details \\
\hline Agus, 2015 & $\begin{array}{l}\text { In her study on supply chain management: the influence of SCM on production performance } \\
\text { and product quality, found that SCM has a positive \& significant effect on production } \\
\text { performance, product quality and also provides evidence that the production performance } \\
\text { construct partially mediates the linkage between SCM \& product quality. }\end{array}$ \\
\hline Lotfi et al, 2013 & $\begin{array}{l}\text { Found that information sharing in supply chain management, in order to increase the } \\
\text { efficiency of the organizational performance in the manufacturing sector. }\end{array}$ \\
\hline Sukati et al, 2012 & $\begin{array}{l}\text { The results of the study revealed that SCM practices have a statistical significant relationship } \\
\text { with supply chain performance. }\end{array}$ \\
\hline Agus, 2011 & $\begin{array}{l}\text { In a study supply chain management, product quality \& business performance conducted } \\
\text { in the Malaysian manufacturing industries considered strategic supplier partnership, lean } \\
\text { production, quality information exchange between supply chain partners and new technology } \\
\& \text { innovation for supply chain management practices. The results reveal that strategic supplier } \\
\text { partnership \& postponement concept is of primary importance and exhibit significant effects } \\
\text { on product quality \& business performance }\end{array}$ \\
\hline Arawati, 2011 & $\begin{array}{l}\text { Study reveals that SCM has significant correlations with supply chain flexibility and business } \\
\text { performance. }\end{array}$ \\
\hline Sukati et al., 2011 & $\begin{array}{l}\text { In their study considered strategic supplier partnership, customer relationship \&information } \\
\text { sharing as important determinants of supply chain management practices conducted in } \\
\text { Malaysian manufacturing industry. The results revealed that the information sharing has the } \\
\text { determinant effect of supply chain responsiveness, followed by customer relationship and } \\
\text { strategic supplier partnership respectively. }\end{array}$ \\
\hline Agus, 2008 & $\begin{array}{l}\text { Strategic supplier partnership and implementation have significant associations with product } \\
\text { quality performance \& business performance }\end{array}$ \\
\hline Berdine et al., 2008 & $\begin{array}{l}\text { In their study analysis of supply chain strategies used by the United State textile and apparel } \\
\text { industries, found that quality, cost, reliability, lead-time, and flexibility are important in the } \\
\text { supply chain strategies. }\end{array}$ \\
\hline \multirow[t]{3}{*}{ Li et al., 2006} & $\begin{array}{l}\text { "SCM practices have been defined as the set of activities undertaken by an organization to } \\
\text { promote effective management of its supply chain". }\end{array}$ \\
\hline & $\begin{array}{l}\text { Conceptualized SCM as a five-dimensional construct. These five dimensions are strategic } \\
\text { supplier partnership, customer relationship, information sharing, quality of information } \\
\text { sharing \& postponement. }\end{array}$ \\
\hline & $\begin{array}{l}\text { In their study on the impact of supply chain management practices on competitive advantage } \\
\text { and organizational performance, identified five distinctive dimensions of SCM practices } \\
\text { namely, strategic supplier partnership, customer relationship, level of information sharing, } \\
\text { quality of information sharing, \& postponement. And the results indicate that the higher } \\
\text { levels of SCM practices lead to enhanced competitive advantage and improved organizational } \\
\text { performance. }\end{array}$ \\
\hline Li et al., 2005 & $\begin{array}{l}\text { In their study on development \& validation of a measurement instrument for studying the } \\
\text { supply chain management practices, identified six distinctive dimensions of SCM practices } \\
\text { namely, strategic supplier partnership, customer relationship, information sharing, } \\
\text { information quality, internal lean practices \& postponement. These six constructs cover } \\
\text { upstream (strategic supplier partnership) \& downstream (customer relationship) sides of a } \\
\text { supply chain, information flow across a supply chain (information sharing \&information } \\
\text { quality), and internal supply chain processes (internal lean practices \& postponement). }\end{array}$ \\
\hline Monczka et al, 1998 & $\begin{array}{l}\text { Considered information sharing and information quality \& participation are the determinants } \\
\text { of strategic supplier alliance. }\end{array}$ \\
\hline
\end{tabular}

\section{Exploratory Study}

Explorative research was conducted to formulate the problem, develop hypothesis and to provide insights \& understanding the problem. The study has used secondary data, discussion with the experts and pilot study to explore the problem and identifying the underlying variables. 
Table 3. List of sub-constructs for SCM Practices

\begin{tabular}{|l|l|l|}
\hline \multicolumn{1}{|c|}{ Sub-Construct } & \multicolumn{1}{|c|}{ Definition } & \multicolumn{1}{c|}{ Contributors } \\
\hline Strategic Supplier Partnership (SSP) & $\begin{array}{l}\text { The long-term relationship between } \\
\text { the organization and its suppliers. It is } \\
\text { designed to leverage the strategic and } \\
\text { operational capabilities of individual } \\
\text { participating organizations to help } \\
\text { them achieve significant ongoing } \\
\text { benefits. }\end{array}$ & $\begin{array}{l}\text { Li et. al., (2005, 2006), Tan et. al., } \\
\text { (2002), Stuart FI (1997), Gunasekaran } \\
\text { et. al., (2001), Monczka et. al., (1998), } \\
\text { Sukati et. al., (2011a, 2012) }\end{array}$ \\
\hline Customer Relationship (CR) & $\begin{array}{l}\text { The entire array of practices that } \\
\text { are employed for the purpose of } \\
\text { managing customer complaints, } \\
\text { building long-term relationships with } \\
\text { customers, and improving customer } \\
\text { satisfaction. }\end{array}$ & $\begin{array}{l}\text { Li et. al., (2005, 2006), Moberg } \\
\text { et. al., (2002), Tan et. al., (2002), } \\
\text { Claycomb et. al., (1999), Day GS } \\
\text { (2000), Magretta J. (1998), Vickey et. } \\
\text { al., (2003), Inda Sukati et. al., (2011a, } \\
\text { 2012) }\end{array}$ \\
\hline Information Sharing (IS) & $\begin{array}{l}\text { The extent to which critical } \\
\text { and proprietary information is } \\
\text { communicated to one's supply chain } \\
\text { partner. }\end{array}$ & $\begin{array}{l}\text { Li et. al., (2005, 2006), Monczka et. } \\
\text { al., (1998), Mentzer et. al., (2000), } \\
\text { Inda Sukati et. al., (2011a, 2012) }\end{array}$ \\
\hline Information Quality (IQ) & $\begin{array}{l}\text { The accuracy, timeliness, adequacy } \\
\text { and credibility of information } \\
\text { exchanged. }\end{array}$ & $\begin{array}{l}\text { Li et. al., (2005, 2006), Inda Sukati et. } \\
\text { al., (2011a, 2012) }\end{array}$ \\
\hline
\end{tabular}

Compiled from Li et. al., (2006) and Abdelsalam \& Fahmy (2009)

\section{Descriptive Study}

The findings of the exploratory research are considered as input for the descriptive research. Descriptive study is used to test the hypothesis which were formulated by exploratory study, and to determine the relationship between the factors identified.

\section{Qualitative Approach}

Qualitative approach enables to understand the industry and was carried out by interviewing the field experts \& the master weavers to get insights of the items which were generated in the study.

\section{Quantitative Approach}

Quantitative approach enables to test the model developed during the process. The study evaluates the inter-relationships among the supply chain management practices and production performance. In this study, the research explored and conceptualized critical dimensions of supply chain management practices (SCMP), and production performance (PPERF).

\section{Population of the Study}

The present study focuses on the relationship between handloom supply chain management practices and production performance. Hence, the master weavers are considered as the population of the study.

\section{Reason for Selecting Master Weavers}

The study considered Master weavers based on the supply chain management practices \& the production performance which is discussed below.

Since Government records are the main sources of data on rural industry in India, and in the case of handloom the government has always focused on the co-operative sector. All the data that is available is related to handloom co-operatives hence, it was of less use for this study. The selection 
Table 4. Production Performance (PPERF)

\begin{tabular}{|c|c|}
\hline Author and Year & Details \\
\hline $\begin{array}{l}\text { Muhammad Babar \& Muhammad Bilal, } \\
2012\end{array}$ & $\begin{array}{l}\text { Have considered sourcing, quality, planning \& on-time delivery to analyse the overall performance of } \\
\text { supply chain management fashion industry of Pakistan. The items considered for quality are availability, } \\
\text { quality of raw material, imported raw material, worker's skill, compensation comparison, worker's } \\
\text { efficiency, focusing on product design and quality control. The study found that quality is significantly } \\
\text { correlated to the dependent variable supply chain management. }\end{array}$ \\
\hline Arawati, 2011 & $\begin{array}{l}\text { Considered volume flexibility and new product flexibility for measuring the supply chain flexibility in } \\
\text { Malaysian manufacturing companies. }\end{array}$ \\
\hline Pal \& Torstensson, 2011 & $\begin{array}{l}\text { The performance of any organization is measured generally in terms of its economic viability (profit- } \\
\text { ratio or growth rate). Competitive priorities, like cost, quality, price, delivery performance (speed), } \\
\text { and flexibility, etc. are also considerable measurement characteristics to determine organizational } \\
\text { performance. Product quality was considered to be the most important success factor for organizations. } \\
\text { The surveyed firms also prioritized the high flexibility in product designing \& Supply Chain Low lead } \\
\text { times and responsiveness. }\end{array}$ \\
\hline Cai et al., 2009 & $\begin{array}{l}\text { Considered flexibility supply chain responsiveness, procurement flexibility, logistics flexibility, } \\
\text { manufacturing flexibility, delivery flexibility, new products flexibility \& Information systems flexibility } \\
\text { as production performance measures. }\end{array}$ \\
\hline Ramamurthy, 2009 & $\begin{array}{l}\text { The three aims of the performance of the production \& operations management are effectiveness, } \\
\text { efficiency, and customer satisfaction. Efficiency and effectiveness are measured by cost, quality, } \\
\text { durability, dependability and reliability. Durability \& dependability are the two factors that often } \\
\text { determine the quality. Durability is the length of active life of the product under given working } \\
\text { conditions and is associated with the relation of good material }\end{array}$ \\
\hline Robb et al., 2008 & $\begin{array}{l}\text { Considered product reliability, after-sale service, delivery dependability, consistent quality, low } \\
\text { production cost, production time, product durability, new products, delivery time, new product } \\
\text { development time, volume flexibility and product mix flexibility as operations performance } \\
\text { measurements. }\end{array}$ \\
\hline Aramyan et al., 2007 & Considered flexibility in terms of Volume flexibility, delivery flexibility, product quality \& reliability. \\
\hline \multirow[t]{2}{*}{ Hallgren, 2007} & "It is difficult to fairly assess manufacturing performance". \\
\hline & $\begin{array}{l}\text { Dimensions used conveniently coincide with the common set of competitive priorities, i.e. quality, } \\
\text { delivery, flexibility \& cost performance. Important to acknowledge is that every dimension, to some } \\
\text { extent is vital for all operations, which one is the most important is just a matter of competitive } \\
\text { positioning. }\end{array}$ \\
\hline Tiwari, 2005 & $\begin{array}{l}\text { Rolls-Royce's key metrics for operational performance are Quality, Cost \&Delivery. The operational } \\
\text { objectives for a supplier are customer response oriented (quality \& on-time delivery), and also } \\
\text { efficiency oriented (product costs \& labour productivity). Quality is an important factor for choosing } \\
\text { a supplier non-cost factors include on-time delivery, technological capabilities \&flexible production } \\
\text { capacity. }\end{array}$ \\
\hline Chen \& Paulraj, 2004 & $\begin{array}{l}\text { In their study used quality, cost, volume flexibility and on-time delivery for measuring operational } \\
\text { performance. }\end{array}$ \\
\hline Gunasekaran. et al., 2004 & $\begin{array}{l}\text { Considered percentage of defects/damages, range of products, on-time delivery for measuring } \\
\text { production performance in UK companies. }\end{array}$ \\
\hline $\begin{array}{l}\text { Boyer \& Lewis, 2002; Schroeder et al., } \\
\text { 2002; Shah, R. \& Ward, 2003; Flynn \& } \\
\text { Flynn, } 2004\end{array}$ & $\begin{array}{l}\text { Financial measures, like profitability and ROI etc. are usually plant level measures that are subject to } \\
\text { many factors outside the scope of manufacturing operations. An attempt to isolate the performance of } \\
\text { the operations function is to utilize measures where the management of operations play an integral part, } \\
\text { i.e. operational performance measures. }\end{array}$ \\
\hline Chan \& Qi, 2003 & $\begin{array}{l}\text { In his study considered delivery cost, delivery reliability: timeliness, error-free, and delivery flexibility } \\
\text { as performance measures. }\end{array}$ \\
\hline Singh et al., 2003 & $\begin{array}{l}\text { In their study modelling supply chain performance of organized garment retailing conducted in north } \\
\text { India considered four metrics namely; inventory metrics, customer metrics, stake holders' metrics and } \\
\text { flexibility metrics (includes volume flexibility, delivery flexibility, and operation flexibility) as key } \\
\text { performance indicators. }\end{array}$ \\
\hline Beamon, 1999 & $\begin{array}{l}\text { In his study considered cost, on-time delivery and flexibility (volume flexibility, delivery flexibility, new } \\
\text { product flexibility \& mix flexibility) for measuring supply chain performance. }\end{array}$ \\
\hline \multirow[t]{2}{*}{ Shin, H. et al, 2000} & Volume flexibility is considered in measuring the buyer (manufacturer) performance. \\
\hline & Delivery reliability and lead-time are considered in measuring the buyer (manufacturer) performance. \\
\hline Bagchi, 1996 & $\begin{array}{l}\text { Determined the metrics of a supply chain system to be used in comparing the competitiveness of } \\
\text { selected companies \& placed each of the } 28 \text { metrics in one of the following four categories: Quality, } \\
\text { Cost, Time \& Diagnostic Measure. }\end{array}$ \\
\hline Neely, 1995 & $\begin{array}{l}\text { Manufacturing performance is measured in terms of flexibility which includes volume flexibility, mix } \\
\text { flexibility \& product flexibility. The quality-based measures of performance have focused on issues for } \\
\text { instance the number of defects and the cost of quality. }\end{array}$ \\
\hline Stewart, 1995 & $\begin{array}{l}\text { Proposed that the metrics \& measures are discussed in the context of the following supply chain } \\
\text { activities/processes: plan, source, make/assemble and delivery/customer. }\end{array}$ \\
\hline Leong et al, 1990 & $\begin{array}{l}\text { Dimensions of manufacturing performance can be defined in terms of quality, delivery speed, delivery } \\
\text { reliability, cost, \& flexibility. }\end{array}$ \\
\hline Mondal, 1989 & $\begin{array}{l}\text { Distribution of yarn in the handloom sector is vitally important for handloom production. In fact, } \\
\text { raw materials account for the overwhelming proportion, about } 75 \text { per cent, of the total variable cost } \\
\text { of the handloom enterprises, of which yarn alone constitutes more than } 66 \text { per cent. The growth and } \\
\text { development of handloom industry is critically dependent upon the adequate and steady supply of raw } \\
\text { materials, especially yarn }\end{array}$ \\
\hline
\end{tabular}


Table 5. List of sub-constructs for production performance

\begin{tabular}{|l|l|}
\hline \multicolumn{1}{|c|}{ Sub- } & \multicolumn{1}{c|}{ Contributors } \\
\hline Quality & $\begin{array}{l}\text { A.Gunasekaran et al. (2004); Muhammad Babar \& Muhammad Bilal (2012); Pal., R \& } \\
\text { Torstensson., H. (2011); Bagchi (1996); Porter (1980); Treacy and Wiersema (1993); } \\
\text { Tiwari, M. (2005); Neely (1995); H. Shin et al., (2000); Garvin (1987) }\end{array}$ \\
\hline Flexibility & $\begin{array}{l}\text { Aramyan } \text { et al. (2007); Robb } \text { et al. (2008); Pal., R \& Torstensson., H. (2011); Porter } \\
\text { (1980); Treacy and Wiersema(1993), Neely (1995); H. Shin et al., (2000) }\end{array}$ \\
\hline Cost & $\begin{array}{l}\text { Adul Hye Mondal (1989); Vinayan, S., (2001); Bagchi (1996); Pal., R \& Torstensson., H. } \\
\text { (2011); A.Aggarwal; Tiwari, M. (2005); Neely (1995) }\end{array}$ \\
\hline Delivery & $\begin{array}{l}\text { Robb } \text { et al. (2008); Porter (1980); Treacy and Wiersema (1993); Tiwari, M. (2005); Stewart } \\
\text { (1995); Neely (1995); H. Shin et al., (2000) }\end{array}$ \\
\hline
\end{tabular}

Figure 2. Gives an idea of the research design used for the study

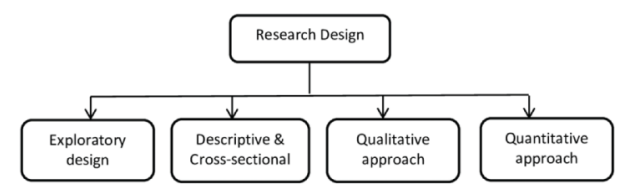

is done on the basis of previous studies and the supply chains for different production structures are shown in Figures 3, 4 and 5.

An independent weaver is the one who possess the instruments of production, purchase raw materials, i e, yarn, and dyes, from the market \& produce the cloth with family labour and sell the product either in the local village market or to the local cloth merchant. There are not many stages involved in this chain; hence, the study is not considered this production structure (see Figure 3).

In Cooperative production structure, the raw material is provided to the weavers and the finished product will be returned to the society itself. The raw material procurement will be done by the APEX organization. Here the society, as well as the weaver, is not directly involved in procuring raw material and marketing the finished product (see Figure 4).

Figure 3. The production structure of Independent weaver

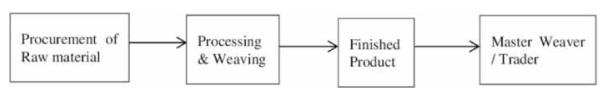

Basically the master weaver is the persons who is involved in the entire chain like, procurement of raw material (interaction with the suppliers and financial aspects), providing the raw material to the weavers to weave (involved in human relation issues) and marketing the finished product (interaction with the customers and financial aspects). All these three steps include the information flow, material flow and monetary flow in between the stake holders involved (see Figure 5).

The master weavers provide employment to the weavers on wage basis. This will be of two types/ categories. In the first type, the weaver will have an own loom and operate from his home and in second type the weavers will not have a loom, they go to the sheds where the master weaver provides with the loom and the raw material. 
Figure 4. The production structure of Weaver working with Co-operative Society

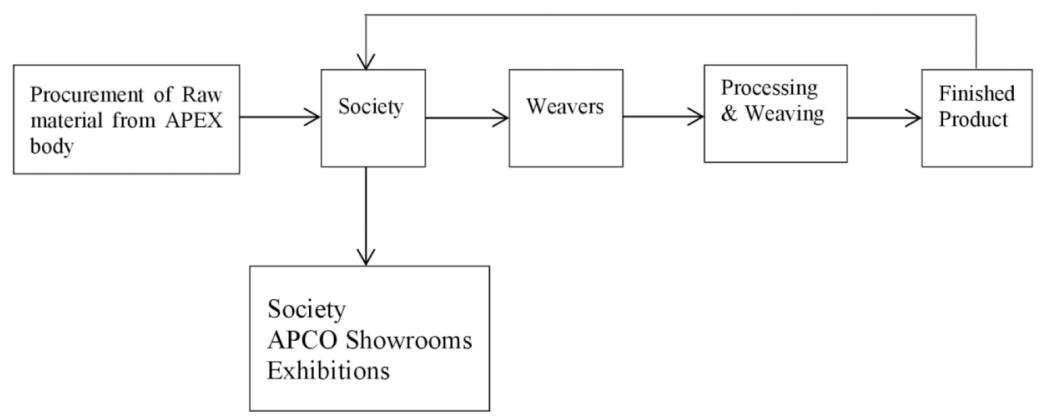

Figure 5. The production structure of Master weaver

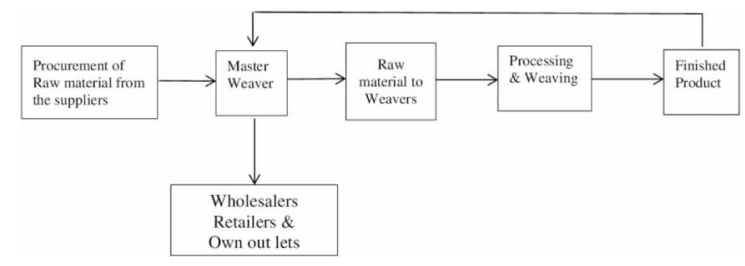

\section{Sampling Technique}

In case of the handlooms, the government has always focused on the co-operative sector hence, all the data that is available is connected to handloom co-operatives and therefore the data was of little use for this study (Bhagavatula, 2009). Since there is no secondary data on master weavers (Dev et al., 2008), the study chose non-probability sampling technique such as purposive sampling.

\section{Sample Size and Justification}

Total 365 valid sample was collected using non-probability purposive sampling method from four select districts located in undivided state of Andhra Pradesh:

1. The study followed the concept of "Five subjects for one variable" as suggested by Hair et al., (2008) to determine the total number of subjects in the sample. As the study identified 48 items, the required sample size should be $240(48 * 5=240)$ for master weavers whereas the valid sample size is 365. Structural Equation Modeling is used to analyse the data, the size of the sample should be large enough to assess the model fit indices (Hair et al., 2010). As recommended by Kelloway (1998) minimum of 200 subjects required to perform structural equation modelling.

Seidler (as cited in Tongco, 2007) has studied different sample sizes of informants selected purposively and found that at least five informants were needed for the data to be reliable.

2. Justification from other studies in the same field.

Bhagavatula (2009), in his study Weaving Social Networks - Performance of small rural firms in India as an outcome of entrepreneurs' social and human capital the sample size taken for the study is 132 . 
Dev et al., (2008), in their study on Economics of Handloom Weaving: A Field Study in Andhra Pradesh has studied three production structures. Under master weaver the sample size was 24.

The studies discussed in the literature also considered 195 - 250 manufacturing firms and the data were collected from the managers of the firms.

\section{Selection of Districts and Justification}

Table 6 shows the previous studies for selecting the particular districts.

After going through the previous studies (see Table 6), discussion with the field experts and the persons who are handloom activists, this study has chosen the four districts namely; Nalgonda, Guntur, Prakasam and Krishna which are having the concentration of Handloom weaving.

\section{DATA ANALYSIS AND RESULTS}

The data was collected using both primary and secondary data. And were analysed using statistical packages such as MS Excel, IBM-Statistical Package for Social Sciences version 21 for windows (SPSS-21) and Analysis of Moment Structures (Amos version 21). Descriptive statistics, correlation, factor analysis (both exploratory and confirmatory), structural equation modelling (SEM) were included in the methods of data analysis.

\section{Demographic Analysis}

The demographic analysis of the 365 respondents are presented below.

$53.2 \%$ of them are members of the society (some of them started working with society as a weaver slowly converted into master weavers) and balance $46.8 \%$ of them are non-members of society.

Most of respondents were in the age group of 35 to 44 years (45.2\%) followed by 45 to 54 years (34.8\%), 55 to 64 years (11.8\%), and 25 to 34 years (7.4\%). The lowest age group of respondents was above 65 years $(0.8 \%)$.

Table 6. Selection of Districts based on the Previous Studies (Justification)

\begin{tabular}{|l|l|l|l|}
\hline \multicolumn{1}{|c|}{ S.No. } & Author and Year & \multicolumn{1}{|c|}{ Study } & \multicolumn{1}{c|}{ Select Districts } \\
\hline 1 & $\begin{array}{l}\text { Mukund,K \& } \\
\text { B.Syama Sundari, } \\
\text { B., 2001 }\end{array}$ & $\begin{array}{l}\text { Traditional Industry in the New Market } \\
\text { Economy - The Cotton Handlooms of Andhra } \\
\text { Pradesh }\end{array}$ & $\begin{array}{l}\text { Nalgonda, Krishna, } \\
\text { Prakasam, Guntur, Kurnool, } \\
\text { Srikakulam, E.Godavari, } \\
\text { Nellore, Kadapa, \& } \\
\text { Mahaboobnagar }\end{array}$ \\
\hline 2 & $\begin{array}{l}\text { Niranjana, S. \& } \\
\text { Vinayan, S., 2001 }\end{array}$ & $\begin{array}{l}\text { Report on Growth and Prospects of the } \\
\text { Handloom Industry }\end{array}$ & $\begin{array}{l}\text { Nalgonda, Krishna, } \\
\text { Prakasam, Guntur, Kurnool, } \\
\text { \& Warangal }\end{array}$ \\
\hline 3 & $\begin{array}{l}\text { Dev, S. M., Galab, Reddy, P. P., \& } \\
\text { Vinayan, S, 2008 }\end{array}$ & $\begin{array}{l}\text { Economics of Handloom Weaving: A Field } \\
\text { Study in Andhra Pradesh }\end{array}$ & $\begin{array}{l}\text { Nalgonda, Krishna, } \\
\text { Prakasam, Guntur, Kadapa, } \\
\text { Vizianagaram, Chittor, } \\
\text { Karimnagar \& Medak }\end{array}$ \\
\hline 4 & $\begin{array}{l}\text { Bhagavatula, S., } \\
\text { 2009 \& 2010 }\end{array}$ & $\begin{array}{l}\text { Weaving Social Networks. Performance of } \\
\text { small rural firms in India as an outcome of } \\
\text { entrepreneurs' social and human capital. } \\
\text { The working of entrepreneurs in a } \\
\text { competitive low technology industry: The } \\
\text { case of master weavers in the handloom } \\
\text { industry. }\end{array}$ & $\begin{array}{l}\text { Nalgonda, Prakasam, } \\
\text { Guntur, Mahaboobnagar \& } \\
\text { Kakinada }\end{array}$ \\
\hline
\end{tabular}


Majority of the respondents fall below SSC in the educational qualification (57.3\%), followed by SSC $(21.1 \%)$, illiterate $(9.6 \%)$, intermediate $(6.6 \%)$, graduation $(4.7 \%)$, professional course $(0.5 \%)$ and lastly post-graduation $(0.3 \%)$.

Majority of the respondents $48.5 \%$ have 14 to 23 years of experience in this field, followed by 4 to 13 years (29\%), 24 to 33 years (15.6\%), 34 to 43 years $(5.2 \%), 44$ to 53 years $(1.4 \%)$ and 54 to 63 years $(0.3 \%)$.

Majority of the respondents operate 1 to 20 looms (71.2\%) followed by 21 to 40 looms (20.5\%), 41 to 60 looms $(7.7 \%)$ and $81-100$ looms $(0.5 \%)$.

Majority of them produce cotton sarees $(32.9 \%)$, cotton \& silk sarees, cotton sarees \& yardage (or dress material) $18.6 \%$ each, $14 \%$ of them produce silk sarees and $6.6 \%$ of them produce bed sheets.

All of them sell their products using different marketing channels. Majority of them sell to trader (41.4\%), followed by trader \& retailer (14.8\%) and trader, retailer \& own outlet (12.9\%).

The final results of Exploratory Factor Analysis for SCMP are shown in Table 7.

\section{Model Fit Summary for SCMP}

The study conducted the initial assessment of model summary. The overall $x^{2}$ value is 379.42 with 182 degrees of freedom at the probability level of 0.001 . It can be observed that the minimum fit indices are achieved (see Table 8). This indicates that AMOS was successful in estimating all model parameters, thereby resulting in a convergent solution. Hence, the Supply Chain Management Practices is found to be fit.

The model fit summary indicates the overall fit and the result showed that the measurement model is reliable and valid for further analysis.

\section{Validity for SCMP}

This section exclusively exhibits the validity analysis of the measurement scale for supply chain management practices. Content validity, convergent validity, discriminant validity, construct validity and predictive validity analysis (see Table 9 and Table 10).

Final results of Exploratory Factor Analysis for PPERF (see Table 11).

\section{Model Fit Summary for PPERF}

The study conducted the initial assessment of model summary. The overall $x^{2}$ value is 181.046 with 69 degrees of freedom at the probability level of 0.001 . It can be observed that the minimum fit indices are achieved (see Table 12). This shows that AMOS was successful in assessing all model parameters, thereby resulting in a convergent solution. Hence, the Production Performance is found to be fit.

The model fit summary shows the overall fit and the result showed that the measurement model is reliable and valid for further analysis.

\section{Validity for PPERF}

This section absolutely exhibits the validity analysis of the measurement scale for production performance. Content validity, convergent validity, discriminant validity, \& construct validity analysis (see Table 13 and Table 14).

\section{Hypothesis Testing}

The hypothesis was tested using AMOS. The independent and dependent variables for this hypothesis are supply chain management practices \& production performance respectively. The result of the structural equation modeling indicates that the path from SCMP to PPERF has a moderate of 0.035. Hence, there is a significant impact of supply chain management practices on production performance. And is in line with Li et al. (2006), Agus (2011,2015).

The structural model for the SCMP and PPERF (see Figure 6) shows the good fit indices and the estimate is significant at 0.001 level (see Tables 15 and Table 16). 
Table 7. Consolidated result (summary) of exploratory factor analysis for SCMP

\begin{tabular}{|c|c|c|c|c|c|}
\hline Variable & & Factor 1 & Factor 2 & Factor 3 & Factor 4 \\
\hline Factor 1 & Strategic Supplier Partnership (SSP) & & & & \\
\hline SSP1 & $\begin{array}{l}\text { I consider Quality as first criterion in selecting } \\
\text { suppliers }\end{array}$ & 0.831 & & & \\
\hline SSP2 & $\begin{array}{l}\text { I include my key suppliers in our planning and } \\
\text { goal-setting activities }\end{array}$ & 0.803 & & & \\
\hline SSP3 & $\begin{array}{l}\text { I believe in long term relationships with the } \\
\text { suppliers }\end{array}$ & 0.836 & & & \\
\hline SSP4 & I emphasize on high quality suppliers & 0.829 & & & \\
\hline SSP5 & I give importance to delivery schedule & 0.808 & & & \\
\hline SSP6 & $\begin{array}{l}\text { I actively involve my key suppliers in new } \\
\text { product development processes }\end{array}$ & 0.808 & & & \\
\hline Factor 2 & Customer Relationship (CR) & & & & \\
\hline CR1 & $\begin{array}{l}\text { I frequently interact with customers to set the } \\
\text { standards }\end{array}$ & & 0.896 & & \\
\hline CR2 & I frequently measure customer satisfaction & & 0.943 & & \\
\hline CR3 & $\begin{array}{l}\text { I frequently determine future customer } \\
\text { expectations }\end{array}$ & & 0.949 & & \\
\hline CR4 & $\begin{array}{l}\text { I facilitate customer's ability to seek assistance } \\
\text { from us }\end{array}$ & & 0.815 & & \\
\hline CR5 & $\begin{array}{l}\text { I periodically evaluate the importance of our } \\
\text { relationship with } \\
\text { my customers }\end{array}$ & & 0.879 & & \\
\hline Factor 3 & Information Sharing (IS) & & & & \\
\hline IS1 & $\begin{array}{l}\text { I inform my weavers in advance of changing } \\
\text { needs }\end{array}$ & & & 0.834 & \\
\hline IS2 & $\begin{array}{l}\text { My weavers share proprietary information } \\
\text { with me }\end{array}$ & & & 0.816 & \\
\hline IS3 & $\begin{array}{l}\text { My weavers keep me fully informed about } \\
\text { issues that affect my business }\end{array}$ & & & 0.688 & \\
\hline IS4 & $\begin{array}{l}\text { My weavers share the knowledge of core } \\
\text { production that effect the business }\end{array}$ & & & 0.801 & \\
\hline IS5 & $\begin{array}{l}\text { Me \& my weavers exchange information that } \\
\text { helps in establishment of business planning }\end{array}$ & & & 0.798 & \\
\hline IS6 & $\begin{array}{l}\text { Me \& my weavers keep each other informed } \\
\text { about the changes that effect the production }\end{array}$ & & & 0.762 & \\
\hline Factor 4 & Information Quality (IQ) & & & & \\
\hline IQ1 & I share information in time with weavers & & & & 0.782 \\
\hline IQ2 & I share accurate information with weavers & & & & 0.884 \\
\hline IQ3 & I share complete information with weavers & & & & 0.797 \\
\hline IQ4 & I share adequate information with weavers & & & & 0.751 \\
\hline
\end{tabular}

\section{CONCLUSION}

This study highlights the relationship between the supply chain management practices and production performance. The results show that supply chain management practices have significant relation with production performance. Supply chain management plays a very important role in manufacturing sector. As per the analysis carried out, master weavers should focus more on SCM practices to improve their production performance (Anumala, 2017). 
Table 8. Model fit summary for SCMP

\begin{tabular}{|l|l|l|l|l|l|l|l|l|l|l|}
\hline \multicolumn{2}{|l|}{} & \multicolumn{3}{|c|}{ Absolute fit indices } & \multicolumn{3}{c|}{ Incremental fit indices } & \multicolumn{3}{c|}{$\begin{array}{c}\text { Parsimony fit } \\
\text { indices }\end{array}$} \\
\hline$\chi 2$ & df & $\chi 2 /$ df & GFI & RMSEA & NFI & TLI & CFI & RFI & AGFI & PNFI \\
\hline 379.42 & 182 & 2.085 & 0.909 & 0.055 & 0.922 & 0.951 & 0.958 & 0.910 & 0.885 & 0.799 \\
\hline
\end{tabular}

Note: $x^{2}$ - chi-square; df-degrees of freedom, GFI-Goodness of fit; RMSEA-Root mean square error of approximation; NFI-Normed fir index; CFIComparative fit index; RFI-Relative fit index; TLI-Tucker-Lewis index; AGFI-Adjusted goodness of fit; \& PNFI-Parsimonious normed fit index.

Table 9. Reliability of SCMP

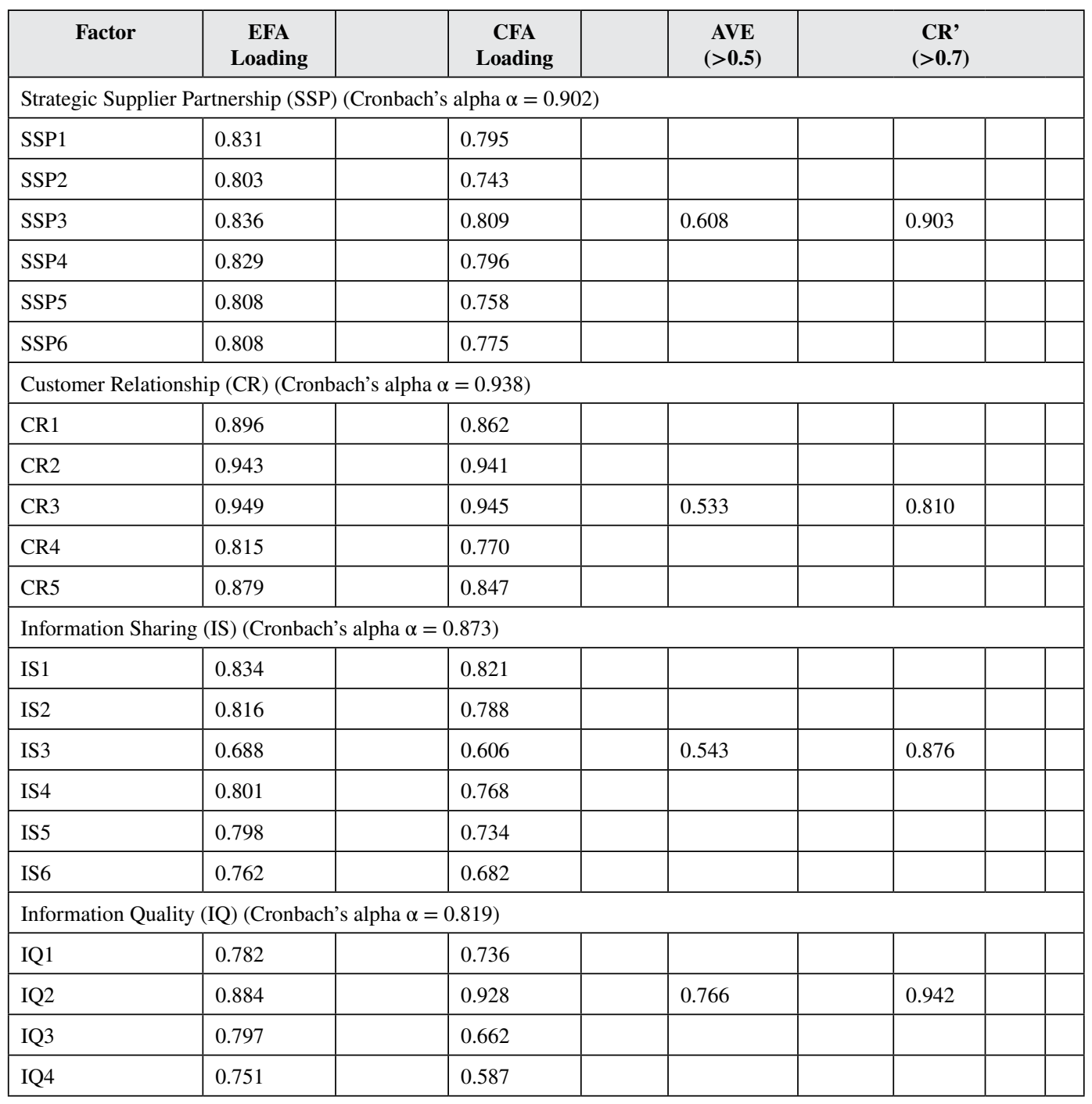

Note: EFA-Exploratory factor analysis; CFA-Confirmatory factor analysis; AVE-Average variance extracted; CR'-Construct Reliability. 
Table 10. Validity Measures for SCMP

\begin{tabular}{|l|l|l|l|l|l|l|l|l|l|}
\hline & \multicolumn{1}{|c|}{$\boldsymbol{\alpha}$} & \multicolumn{1}{|c|}{ CR' } & \multicolumn{1}{c|}{ AVE } & MSV & ASV & \multicolumn{1}{c|}{ IS } & SSP & IQ & CR \\
\hline IS & 0.873 & 0.876 & 0.543 & 0.010 & 0.004 & 0.737 & & & \\
\hline SSP & 0.902 & 0.903 & 0.608 & 0.010 & 0.004 & 0.102 & 0.780 & & \\
\hline IQ & 0.819 & 0.942 & 0.766 & 0.006 & 0.002 & 0.010 & 0.012 & 0.875 & \\
\hline CR & 0.938 & 0.810 & 0.533 & 0.006 & 0.002 & 0.008 & 0.009 & 0.080 & 0.730 \\
\hline
\end{tabular}

Note: a- Cronbach's alpha, CR'-Construct Reliability, AVE-Average Variance Extracted, MSV-Maximum Shared variance, ASV-Average Shared Squared Variance, IS-Level of Information Sharing, SSP-Strategic Supplier Partnership, IQ-Level of Information Sharing, CR-Customer Relations

Table 11. Final results of Exploratory Factor Analysis for PPERF

\begin{tabular}{|c|c|c|c|c|c|}
\hline Variable & & Factor 1 & Factor 2 & Factor 3 & Factor 4 \\
\hline Factor 1 & Quality & & & & \\
\hline Q3 & Focusing on product design & 0.989 & & & \\
\hline Q4 & $\begin{array}{l}\text { Product made to specifications } \\
\text { (Conformance quality) }\end{array}$ & 0.987 & & & \\
\hline Q5 & Damages/defects & 0.990 & & & \\
\hline Q6 & $\begin{array}{l}\text { Basic characteristics of the product are } \\
\text { good (Performance quality) }\end{array}$ & 0.994 & & & \\
\hline Q7 & Quality of raw material is good & 0.956 & & & \\
\hline Q8 & $\begin{array}{l}\text { Workers skills \& efficiency is up to } \\
\text { the mark in processing }\end{array}$ & 0.966 & & & \\
\hline Factor 2 & Flexibility & & & & \\
\hline $\mathrm{F} 1$ & $\begin{array}{l}\text { Mix flexibility (Ability to produce } \\
\text { wide range of products) }\end{array}$ & & 0.908 & & \\
\hline $\mathrm{F} 2$ & $\begin{array}{l}\text { Volume flexibility (Ability to produce } \\
\text { whatever volume the customer needs) }\end{array}$ & & 0.874 & & \\
\hline F3 & Product variety & & 0.907 & & \\
\hline Factor 3 & Delivery & & & & \\
\hline D1 & On-time delivery & & & 0.918 & \\
\hline D2 & Lead-time & & & 0.849 & \\
\hline D3 & Delivery Speed & & & 0.898 & \\
\hline Factor 4 & Cost & & & & \\
\hline $\mathrm{C} 1$ & Raw material cost & & & & 0.896 \\
\hline $\mathrm{C} 2$ & Labour cost & & & & 0.908 \\
\hline
\end{tabular}

Table 12. Model fit summary for PPERF

\begin{tabular}{|l|l|l|l|l|l|l|l|l|l|l|l|}
\hline \multicolumn{2}{|c|}{} & \multicolumn{3}{c|}{ Absolute fit indices } & \multicolumn{3}{c|}{$\begin{array}{c}\text { Parsimony fit } \\
\text { indices }\end{array}$} & \multicolumn{3}{c|}{ Incremental fit indices } \\
\hline$\chi 2$ & df & $\chi 2 /$ df & GFI & RMSEA & AGFI & PNFI & NFI & TLI & CFI & RFI \\
\hline 181.046 & 69 & 2.624 & 0.936 & 0.067 & 0.903 & 0.743 & 0.980 & 0.984 & 0.988 & 0.974 \\
\hline
\end{tabular}


Table 13. Reliability of PPERF

\begin{tabular}{|c|c|c|c|c|c|c|}
\hline Factor & $\begin{array}{c}\text { EFA } \\
\text { Loading }\end{array}$ & & $\begin{array}{c}\text { CFA } \\
\text { Loading }\end{array}$ & $\operatorname{AVE}(>0.5)$ & $\mathbf{C R}^{\prime}(>$ & \\
\hline \multicolumn{7}{|c|}{ Quality (Q) (Cronbach's alpha $\alpha=0.989$ ) } \\
\hline Q3 & & 0.989 & 0.993 & & & \\
\hline Q4 & & 0.987 & 0.992 & & & \\
\hline Q5 & & 0.990 & 0.994 & 0.950 & 0.991 & \\
\hline Q6 & & 0.994 & 0.999 & & & \\
\hline Q7 & & 0.956 & 0.927 & & & \\
\hline Q8 & & 0.966 & 0.942 & & & \\
\hline \multicolumn{7}{|c|}{ Flexibility (F) (Cronbach's alpha $\alpha=0.942$ ) } \\
\hline $\mathrm{F} 1$ & & 0.908 & 0.967 & & & \\
\hline $\mathrm{F} 2$ & & 0.874 & 0.851 & 0.851 & 0.945 & \\
\hline F3 & & 0.907 & 0.946 & & & \\
\hline \multicolumn{7}{|c|}{ Delivery (D) (Cronbach's alpha $\alpha=0.935)$} \\
\hline D1 & & 0.898 & 0.947 & & & \\
\hline D2 & & 0.918 & 0.826 & 0.835 & 0.938 & \\
\hline D3 & & 0.849 & 0.962 & & & \\
\hline \multicolumn{7}{|c|}{ Cost (C) (Cronbach's alpha $\alpha=0.887$ ) } \\
\hline $\mathrm{C} 1$ & & 0.896 & 0.925 & 0.800 & 0.889 & \\
\hline $\mathrm{C} 2$ & & 0.908 & 0.863 & & & \\
\hline
\end{tabular}

Note: AVE = Average Variance Extracted, $C R^{\prime}=$ Construct Reliability

Table 14. Validity Measures for PPERF

\begin{tabular}{|l|l|l|l|l|l|l|l|l|l|}
\hline & \multicolumn{1}{|c|}{$\boldsymbol{\alpha}$} & CR' & AVE & MSV & ASV & Delivery & Quality & Flexibility & Cost \\
\hline Delivery & 0.935 & 0.938 & 0.835 & 0.324 & 0.180 & 0.914 & & & \\
\hline Quality & 0.989 & 0.991 & 0.950 & 0.004 & 0.001 & 0.013 & 0.975 & & \\
\hline Flexibility & 0.942 & 0.945 & 0.851 & 0.324 & 0.176 & 0.569 & 0.004 & 0.923 & \\
\hline Cost & 0.887 & 0.889 & 0.800 & 0.216 & 0.141 & 0.465 & 0.062 & 0.452 & 0.895 \\
\hline
\end{tabular}

Note: $\alpha$ - Cronbach's alpha, CR'-Construct Reliability, AVE-Average Variance Extracted, MSV-Maximum Shared variance, ASV-Average Shared Squared Variance.

Figure 6. The structural model for Supply Chain Management Practices and Production Performance

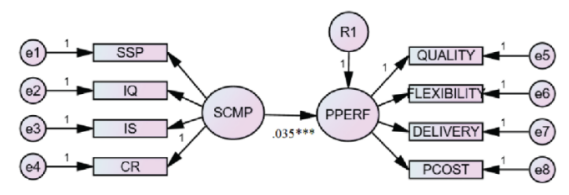


Table 15. Model Fit for SCMP-PPERF

\begin{tabular}{|l|l|c|l|l|c|c|c|c|c|c|}
\hline & \multicolumn{1}{|c|}{$\boldsymbol{\chi 2 / d f}$} & GFI & AGFI & RMSEA & NFI & TLI & CFI & RFI & PNFI & PGFI \\
\hline SCMP $\rightarrow$ PPERF & 3.030 & 0.979 & 0.947 & 0.079 & 0.973 & 0.969 & 0.979 & 0.959 & 0.648 & 0.932 \\
\hline
\end{tabular}

Note: $x^{2}$ /df-degrees of freedom, GFI-Goodness of fit; AGFI-Adjusted goodness of fit; RMSEA-Root mean square error of approximation; NFI-Normed fir index; TLI-Tucker-Lewis index; CFI-Comparative fit index; RFI-Relative fit index; PNFI-Parsimonious normed fit index; \& PGFI-Parsimony goodness of fit index.

Table 16. Result of hypothesis based on SEM

\begin{tabular}{|l|l|l|l|l|}
\hline & & & \multicolumn{1}{|c|}{ Estimate } & P \\
\hline SCMP & $\rightarrow$ & PPERF & 0.035 & $* * *$ \\
\hline
\end{tabular}

If any further study has to be carried on this topic, one can think of using system dynamics. As cited by Gafi \& Javadian (2018), there are several reasons that make system dynamics System dynamics as a good methodology for modeling of the supply chains: first, the ability to understand the system as a whole, then analyzing the interactions between the various components of the integrated system and finally supplying feedback without decomposing (Özbayrak et al., 2007). 


\section{REFERENCES}

Agus, A. (2011). Supply chain management, product quality and business performance. Paper presented at the International Conference on Sociality and Economics Development IPEDR. Retrieved from http://www.ipedr. com/vol10/19-E10021.pdf

Agus, A. (2015). Supply Chain Management: The Influence of SCM on Production Performance and Product Quality. Journal of Economics, Business and Management. 1046-1053. 10.7763/JOEBM.2015.V3.332

Agus, A., \& Hassan, Z. F. (2008). The Strategic Supplier Partnership in a Supply Chain Management with Quality and Business Performance. International Journal of Business and Management Science, 1(2), 129-145. http://www.safaworld.org/ijbms/Necdoc/

Anilkumar, E. N., \& Sridharan, R. (2019). Sustainable Supply Chain Management: A Literature Review and Implications for Future Research. International Journal of System Dynamics Applications, 8(3), 15-52. doi:10.4018/IJSDA.2019070102

Anumala, K. (2017). Impact of supply chain management practices on production performance and product quality in Indian handloom industry: a study of master weavers of undivided Andhra Pradesh (Unpublished doctoral dissertation). University of Hyderabad, India.

Aramyan, L. H., Oude Lansink, A. G., Van Der Vorst, J. G., \& Van Kooten, O. (2007). Performance measurement in agri-food supply chains: A case study. Supply Chain Management, 12(4), 304-315. doi:10.1108/13598540710759826

Arawati, A. (2011). Supply chain management, supply chain flexibility and business performance. Journal of Global Strategic Management, 9, 134-145. http://www.acarindex.com/dosyalar/makale/acarindex-1423906231. pdf

Babar, M., \& Bilal, M. (2012). Effectiveness of Supply Chain Management on Fashion Industry of Pakistan. Proceedings of 2nd International Conference on Business Management. Retrieved from https://www.umt.edu. pk/icobm2012/pdf/2C-66P.pdf

Bagchi, P. K. (1996). Role of benchmarking as a competitive strategy: The logistics experience. International Journal of Physical Distribution \& Logistics Management, 26(2), 4-22. doi:10.1108/09600039610113173

Beamon, B. M. (1999). Measuring supply chain performance. International Journal of Operations \& Production Management, 19(3), 275-292. doi:10.1108/01443579910249714

Berdine, Parrish, Cassill, Oxenham, \& Jones. (2008). Analysis of supply chain strategies used by the united states textile and apparel industries. Research Journal of Textile and Apparel, 12(3), 1-17. Retrieved from www. rjta.org/download.php?paper=1\&paper_id=08_3_01

Bhagavatula, S. (2009). Weaving Social Networks. In Performance of small rural firms in India as an outcome of entrepreneurs' social and human capital. Vrije Universiteit Amsterdam.

Bhagavatula, S. (2010). The working of entrepreneurs in a competitive low technology industry: The case of master weavers in the handloom industry. IIM Bangalore Research Paper (321). Retrieved fromPapers.ssrn. com/Sol3/papers.cfm? abstract_id=2122434

Boyer, K. K., \& Lewis, M. W. (2002). Competitive priorities: Investigating the need for trade-offs in operations strategy. Production and Operations Management, 11(1), 9-20. doi:10.1111/j.1937-5956.2002.tb00181.x

Cai, J., Liu, X., Xiao, Z., \& Liu, J. (2009). Improving supply chain performance management: A systematic approach to analyzing iterative KPI accomplishment. Decision Support Systems, 46(2), 512-521. doi:10.1016/j. dss.2008.09.004

Chan, F. T., \& Qi, H. J. (2003). An innovative performance measurement method for supply chain management. Supply Chain Management, 8(3), 209-223. doi:10.1108/13598540310484618

Chandra, C., \& Kumar, S. (2000). An application of a system analysis methodology to manage logistics in a textile supply chain. Supply Chain Management, 5(5), 234-245. doi:10.1108/13598540010350493

Chen, I. J., \& Paulraj, A. (2004). Towards a theory of supply chain management: The constructs and measurements. Journal of Operations Management, 22(2), 119-150. doi:10.1016/j.jom.2003.12.007 
Dev, S., Galab, S., Reddy, P., \& Vinayan, S. (2008). Economics of Handloom Weaving: A Field Study in Andhra Pradesh. Economic and Political Weekly, 43(21), 43-51. http://www.jstor.org/stable/40277496

Flynn, B. B., \& Flynn, E. J. (2004). An exploratory study of the nature of cumulative capabilities. Journal of Operations Management, 22(5), 439-457. doi:10.1016/j.jom.2004.03.002

Gafi, E. G., \& Javadian, N. (2018). A System Dynamics Model for Studying the Policies of Improvement of Chicken Industry Supply Chain. International Journal of System Dynamics Applications, 7(4), 20-37. doi:10.4018/ IJSDA.2018100102

Giri, S., \& Rai, S. S. (2013). Dynamics of garment supply chain. International Journal of Managing Value and Supply Chains, 4(4), 29-42. doi:10.5121/ijmvsc.2013.4403

Gunasekaran, A., Patel, C., \& McGaughey, R. E. (2004). A framework for supply chain performance measurement. International Journal of Production Economics, 87(3), 333-347. doi:10.1016/j.ijpe.2003.08.003

Haddad, M., \& Otayek, R. (2019). Assessing the Sustainment of a Lean Implementation Using System Dynamics Modeling: A Case Study of Apparel Manufacturing in Lebanon. International Journal of System Dynamics Applications, 8(4), 14-29. doi:10.4018/IJSDA.2019100102

Hair, J. F. Jr, Black, W. C., Babin, B. J., Anderson, R. E., \& Tatham, R. L. (2008). Multivariate Data Analysis (6th ed.). Pearson Prentice Hall.

Hair, J. F. J., Black, W. C., Babin, B. J., \& Anderson, R. E. (2010). Multivariate Data Analysis (7th ed.). Prentice Hall.

Hallgren, M. (2007). Manufacturing strategy, capabilities and performance. Linkoping University.

Iqbal, M. C., \& Shalij, P. R. (2019). Supply Chain Risk Assessment in the Ornamental Fish Supply Chain. International Journal of System Dynamics Applications, 8(2), 36-50. doi:10.4018/IJSDA.2019040103

Kaya, Ö., \& Öztürk, F. (2014). A Research on the Applications of Supply Chain in Textile-Clothing Industry. International Journal of Innovation, Management and Technology, 5(5), 334-338. doi:10.7763/IJIMT.2014. V5.536

Kelloway, E. K. (1998). Using LISREL for structural equation modeling: A researcher's guide. Sage Publications.

Kumar, A., \& Anbanandam, R. (2019). Multimodal Freight Transportation Strategic Network Design for Sustainable Supply Chain: An OR Prospective Literature Review. International Journal of System Dynamics Applications, 8(2), 19-35. doi:10.4018/IJSDA.2019040102

Lam, J. K., \& Postle, R. (2006). Textile and apparel supply chain management in Hong Kong. International Journal of Clothing Science and Technology, 18(4), 265-277. doi:10.1108/09556220610668491

Lee, Y. (2000). Study of Relationships between Apparel Manufacturers' Supply Chain Management, Company Characteristics, and Inventory Performance. Virginia Polytechnic Institute and State University.

Lee, Y., \& Kincade, D. H. (2003). US apparel manufacturers' company characteristic differences based on SCM activities. Journal of Fashion Marketing and Management, 7(1), 31-48. doi:10.1108/13612020310464359

Leong, G. K., Snyder, D. L., \& Ward, P. T. (1990). Research in the process and content of manufacturing strategy. Omega, 18(2), 109-122. doi:10.1016/0305-0483(90)90058-H

Li, S., Ragu-Nathan, B., Ragu-Nathan, T., \& Rao, S. S. (2006). The impact of supply chain management practices on competitive advantage and organizational performance. Omega, 34(2), 107-124. doi:10.1016/j. omega.2004.08.002 PMID:17876965

Li, S., Rao, S. S., Ragu-Nathan, T., \& Ragu-Nathan, B. (2005). Development and validation of a measurement instrument for studying supply chain management practices. Journal of Operations Management, 23(6), 618-641. doi:10.1016/j.jom.2005.01.002

Lotfi, Z., Mukhtar, M., Sahran, S., \& Zadeh, A. T. (2013). Information sharing in supply Chain management. Procedia Technology, 11, 298-304. doi:10.1016/j.protcy.2013.12.194

Ministry of Textiles Government of India. (2019). Annual Report 2018-19. Retrieved from http://texmin.nic.in/ sites/default/files/Textiles-AnnualReport2018-2019\%28English\%29.pdf 
Monczka, R. M., Petersen, K. J., Handfield, R. B., \& Ragatz, G. L. (1998). Success Factors in Strategic Supplier Alliances: The Buying Company Perspective. Decision Sciences, 29(3), 553-577. doi:10.1111/j.1540-5915.1998. tb01354.x

Mondal, A. H. (1989). Distribution of Yarn in the Handloom Sector of Bangladesh: A Further Study. Bangladesh Development Studies, 101-129.

Mukunad, K., \& Syama Sundari, B. B. (2001). Traditional Industry in the New Market Economy - The Cotton Handlooms of Andhra Pradesh. New Delhi: Sage Publications India Pvt. Ltd.

Narsaiah, M. L. (2004). Economics of Handloom Industry. Sonali Publications.

Neely, A., Gregory, M., \& Platts, K. (1995). Performance measurement system design: A literature review and research agenda. International Journal of Operations \& Production Management, 15(4), 80-116. doi:10.1108/01443579510083622

Nema, N., Nougriaya, M. S., Soni, M. S., \& Talankar, M. A. (2013). Green Supply Chain Management Practices in Textile and Apparel Industries: Literature Review. International Journal of Engineering Technology \& Management Research, Issue, (1), 330-336.

Niranjana, S. \& Vinayan, S. (2001). Report on Growth and Prospects of the Handloom Industry. Retrieved fromPlanningcommission.nic.in/reports/ sereports/ser/ stdy_handloom.pdf

Pal, R., \& Torstensson, H. (2011). Aligning critical success factors to organizational design: A study of Swedish textile and clothing firms. Business Process Management Journal, 17(3), 403-436. doi:10.1108/14637151111136351

Ramamurthy. (2009). Production and Operations Management (2 ${ }^{\text {nd }}$ ed.). New Delhi: New Age International.

Robb, D. J., Xie, B., \& Arthanari, T. (2008). Supply chain and operations practice and performance in Chinese furniture manufacturing. International Journal of Production Economics, 112(2), 683-699. doi:10.1016/j. ijpe.2007.04.011

Schroeder, R. G., Bates, K. A., \& Junttila, M. A. (2002). A resource-based view of manufacturing strategy and the relationship to manufacturing performance. Strategic Management Journal, 23(2), 105-117. doi:10.1002/smj.213

Shah, R., \& Ward, P. T. (2003). Lean manufacturing: Context, practice bundles, and performance. Journal of Operations Management, 21(2), 129-149. doi:10.1016/S0272-6963(02)00108-0

Shin, H., Collier, D., \& Wilson, D. (2000). Supply management orientation and supplier/buyer performance. Journal of Operations Management, 18(3), 317-333. doi:10.1016/S0272-6963(99)00031-5

Singh, R., Sandhu, H., Metri, B., \& Singh, M. P. (2003). Modeling supply chain performance of organized garment retailing. International Journal of Scientific and Research Publications, 3(3), 1-10.

Stewart, G. (1995). Supply chain performance benchmarking study reveals keys to supply chain excellence. Logistics Information Management, 8(2), 38-44. doi:10.1108/09576059510085000

Sukati, I., Hamid, A. B., Baharun, R., \& Yusoff, R. M. (2012). The Study of Supply Chain Management Strategy and Practices on Supply Chain Performance. Management, 1877(0428), 225-233. doi:10.1016/j. sbspro.2012.03.185

Sukati, I., Hamid, A. B. A., Baharun, R., Tat, H. H., \& Said, F. (2011). An investigation of the relationship between supply chain management practices and competitive advantage of the firm. Contemporary Marketing Review, 1(4), 1-13.

Tiwari, M. (2005). An exploration of supply chain management practices in the aerospace industry and in RollsRoyce. Massachusetts Institute of Technology.

Tongco, M. D. C. (2007). Purposive sampling as a tool for informant selection. Retrieved from http:// s3.amazonaws.com/academia.edu.documents/34833273/I1547-3465-05-147.pdf 
International Journal of System Dynamics Applications

Volume $10 \cdot$ Issue $2 \cdot$ April-June 2021

Kalyani Anumala (PhD) has done her Post Graduate Diploma in Garment Manufacturing Technology. Done her MBA and PhD (Supply Chain Management) from University of Hyderabad. She has 8 years of industry experience in apparel export firms. Presently working as an assistant professor (for 2.5 years). 